\title{
Is reflective practice an essential component of becoming a professional teacher?
}

\begin{abstract}
This paper explores the concept of reflective practice and its role in the professionalisation of student teachers. There is an examination of the requirements to become a qualified teacher and how these requirements have determined practice. After looking at the recent evolution, of state requirements for initial teacher education, in England, it investigates the place of reflective practice within that process and to what extent reflective practice is still needed to become a teacher. It presents the different interpretations of reflective practice and the role of professionalism in the journey to qualified teaching status (QTS).
\end{abstract}

\section{Introduction}

When studying the history of initial teacher education Robinson (2006, p.19) argues that teacher education is fraught with tensions. These manifest themselves within a number of on-going debates about the skills and professional knowledge needed to become an effective teacher, the balance between theory and practice in the training process; the diversity of routes into teaching and their associated training; and the increasing government control of teacher education. Reflective practice is encouraged and often 'held up' as an essential part of being a professional, but what it is, what forms it can take and what is its purpose are core questions to be answered in this paper. It is currently both implicit and explicit in the current Teacher Training Standards and therefore features in the training elements of initial teacher education programmes. These programmes do or should go beyond explaining how to reflect on and evaluate lesson planning and performance to developing an awareness of the context within which teachers are teaching and the hidden agendas and power relationships within which they are operating.

There are many theories which explore the different dimensions and complexities of reflective practice which are addressed here. What follows is first a discussion of theories of reflective practice followed by a discussion of the role of reflective practice in the Teaching Standards. The conclusions reached in the paper is that reflective practice, in its various guises, is needed to become a professional teacher but that recent government policy changes to teacher training may threaten that. 


\section{Different manifestations of reflective practice}

Interpretations of reflective practice vary between different professions and even within the same professional field, such as education. There are some areas of agreement and these are that reflective practice is the 'process of learning through and from experience towards greater insights of self or practice' (Finlay, 2008, p.1). The process of learning is the basis for all interpretations of the contentious term, and whatever form reflective practice takes the reflective practitioner should learn and grow from engaging with it. Reflective practice is therefore used within teacher education to enable the student teacher to learn. The contention occurs when discussing what it is exactly the student should be learning from when engaging in reflective practice.

A technical approach to reflective practice advocates learning from actual teaching - how well did a lesson go, was it well planned, did it achieve its objective, how could it be done better, whereas a more holistic interpretation of reflective practice may encourage a critical reflection on what is the purpose of teaching that lesson in the way it is required and who decides and has power to control and determine what is done. This reflection on the role of power and the social field(s) the students finds themselves in (Schon, 1987, Bourdieu, 1990). There are also advocates of reflexivity or personal reflection and the 'turning of the lens' on oneself (Loughran, 2006).

Reflective practice has grown in significance over the last 30 years. It gathered pace after Schon's first book on reflective practice: Theory in practice: Increasing professional effectiveness (in collaboration with Argyris), in 1974, and continued with subsequent writings, including the use of reflective practice in education, with: The Reflective Turn: Case Studies In and On Educational Practice in 1991. Schon, a prominent theoirist in reflective practice, explored types of knowledge and how we require it. Knowing-in-action is the unconscious practice that occurs when a person's acts are based on prior experience. The person does not actively reflect on the event but uses tacit knowledge before engaging in action. Tacit knowledge is the knowledge the professional has built up from different experiences they have had. As the student teacher moves to becoming a professional their tacit knowledge increases and influences their actions. This knowledge is in the action and is unconscious, whereas Schon's (1995) reflection-in-action is the conscious reflection that is undertaken 'on the spot'; it is a reaction to what is occurring at the time, rather than an instant 
reaction using tacit knowledge. Schon's last type of reflection is reflection-on-action. Reflection-on-action occurs after the event and is a continual process of review and improvement; this is illustrated by a three stage model:

\section{Providing students with technical training}

2. Helping the students think like a professional

3. Enabling the students to develop a new form of understanding and action

The practitioner is encouraged to use 'reflection-on-action' by continuously reflecting on a problem to generate new knowledge and using the new knowledge to solve a problem or dilemma. According to Schon (1987) this cyclical process would improve the standard of the professional in their field. Schon's 'reflection on action' is present in the Teaching Standards demanded by the state (TDA, 2007). Student teachers need to evidence how they reflect and improve their practice during their training.

Schon's (1987) technical approach to reflection has been questioned by Reynolds (1998) who advocates the use of critical reflective practice. Again, this term is not without challenge, as interpretations range from reflecting on the social environment to a more inward looking interpretation of engaging in personal reflection. Zeichner (1996, p.1) believes that a practitioner has not engaged in reflective practice unless they have questioned the: 'context in which they teach... and their own individual's beliefs'. Critical reflection encourages reflections on the practitioner's past experiences, ideological beliefs and the social context in which he/she is operating. This definition is more holistic and moves away from the technical reflective practice advocated by Schon (1987). Fook (2006, p.53) expands Zeichner's definition and says the practice of reflection:

...enables an understanding of the way (socially dominant) assumptions may be socially restrictive, and thus enables new, more empowering ideas and practices. Critical reflection thus enables social change beginning at individual levels. Once individuals become aware of the hidden power of ideas they have absorbed unwittingly from their social contexts, they are then freed to make choices on their own terms.

The use of critical reflective practice is a questioning of the norm and the emancipation of the practitioner from the social constraints and practices that are taken for granted. Critical reflective practice is not part of the current Teaching Standards and if it does occur it is 
because it is advocated by the Higher Educational Institution (HEI) the student teacher belongs to.

Reflective practice also includes the action of reflexivity. Reflexivity is interpreted from the extremity of holistic reflexivity at one end of a spectrum and deep recollection, by oneself, at the other. For Bleakley (1999) ethical considerations are an important strand in reflexivity and how we concern ourselves with 'otherness'. There are numerous authors who agree with Bleakley's need for reflexivity to navigate the modern world and its ever changing being.

Archer (2007, p.94) emphasises the importance of reflexivity in navigating our way through the world, and defines it as 'the regular exercise of the mental ability, shared by all normal people, to consider themselves in relation to their social context and vice versa'. Archer stresses how we need to realise and reflect on the influence of social context, structure and human agency. Reflexivity for her, is considering the external influences in terms of agencies. Archer's (2007) social theory sheds light on this need for reflexivity, in the teaching profession, by analysing the contextual structures that form and are formed by the practices of 'the teacher'. Her beliefs concur with critical realism that structures and agents are intertwined and action is what connects these two. According to Archer (2007, p.209) the actions that connect structure and agent take two forms: that of transformation (morphogenetic) and reproduction (morphostatic). Morphogenetic is when the agents' actions transform the social structures and cultural systems in which they operate and morphostatic is the reproduction of those systems.

In the instance of teachers it would be their practice influenced by their subjective concerns, such as values, and their objective considerations, such as the curriculum and different assessments that influence their actions. These actions may reproduce the same structure or may transform it. The teacher may deliberate over their own actions given their own concerns, beliefs and whether the action is context dependent. This deliberation is an internal conversation the teacher has which encapsulates Archer's (2007) interpretation of reflexivity. Reflexivity involves the teacher's own subjective and objective concerns in a given context before action is taken. The context may be such that deliberation leads to a reproduction of the status quo but reflexivity is needed in case it leads to necessary morphogenetic. Student teachers who are placed in one placement for the majority of their ITE are less likely to question the status quo, due to their limited experience. The knowledge gained from being 
part of an HEI, and the breadth of experience, would contribute to an increase in critical reflection and reflexivity.

Some authors interchange reflexivity and critical reflective practice, but Finlay (2003, 2008) sees these concepts more as a continuum. Firstly, there is 'reflection' and the engagement of technical reflective practice; next there is an engagement with 'critical reflection'; and the last stage of the continuum is reflexivity' and the practice of continual self-awareness of changing identity. Finlay separates reflection on the social structures (critical reflection) and reflection on oneself (reflexivity), whereas Archer (2007) regards both types of reflective practice as reflexivity. By applying Finlay's theory the student teacher moves along the continuum as they gain more experience, engaging in reflection, critical reflection and then reflexivity, indicating that reflexivity is the ultimate form of reflective practice. Reflection and the technical approach to reflective practice is only the first step towards reflective practice. The reflective practice, that is advocated by the teaching standards (DfE, 2012), only allows the student teacher to reach the first step of the continuum, as critical reflection and reflexivity are not mentioned or advocated.

\section{The history of reflective practice in teacher education}

In most professional groups reflective practice has a significant part to play in professional development. The practice of reflection has been adopted in teacher education and has now become a defining feature of teacher professionalism. However, reflective practice has not always been prominent in teacher education. In England, prior to the late 1980s teacher educators had significant freedom in deciding their own curriculum but this changed during the 1980s and 1990s with the increase in state control of ITE (Emery, 1998). The Council for the Accreditation of Teacher Education (CATE) was established in 1984 to regulate ITE. To begin with regulation started with the development of student teacher competencies. Initially these competences were: 'applied loosely and on a voluntary basis by accredited institutions' (Robinson, 2006, p.29). They were neither a legal requirement nor enforced. It was after the creation of Ofsted (Office for Standards in Education), in 1992, and the subsequent inspection arrangements for ITE that consistency, in terms of competencies and grading, was introduced (DfE, 1992). Once Ofsted started to inspect teacher education, teacher educators became accountable for their performance. 
In 1998 a 'national curriculum' for teacher education was published in England. This curriculum was an 85 page document containing very detailed requirements of teacher educators. The curriculum, however, was seen as unworkable (Whitty, 2006). It contained 800 standards, which were listed under four broad headings: Subject Knowledge, Planning, Teaching and Classroom Management, Monitoring and Assessment, Recording and Reporting and other Professional Requirements (DfEE, 1998). There were also subject specific standards for maths, English and science.

Ofsted was required to inspect ITE providers and their compliance with the new curriculum. The latter was seen by many as a restriction for HEIs. Furlong, Miles, Whiting and Whitty (2000) argue that the 1998 curriculum was purposely prescriptive in order to restrict the influence of the HEIs over ITE. According to Pollard and Newman (2010) the 1998 curriculum focused on the skills of the teacher rather than their professional attributes, such as reflective practice. Reflective practice was not mentioned at all in the 1998 curriculum.

In 2002 there was a change in focus by the government from a curriculum, for teacher educators, to a required standard for student teachers. In the 2002 Teaching Standards (TTA, 2002, no page number) there was no specific reference to reflective practice but Standard 1.8 implied reflective practice as it requires student teachers to be:

... able to improve their own teaching, by evaluating it, by learning from the effective practice of others and by using research, inspection and other evidence.

This standard can be seen as an example of Finlay's (2008) reflection and demonstrates what Schon (1983) refers to as 'reflecting on practice' which is the process of reviewing a lesson after it occurs. The teaching standards were revised again in 2007 by the newly formed Teaching and Development Agency for schools (TDA). This new framework covered the whole of a teacher's career rather than just the initial period of teacher education. It is in these standards that for the first time reflective practice appears by name. Reflective practice was needed to satisfy Teaching Standard 7 (TDA, 2007, no page number). The student teacher had to show they could:

...reflect on and improve their practice, and take responsibility for identifying and meeting their developing professional needs. 
The 2007 Teaching Standards became the basis of the teacher's performance management system replacing the ad hoc appraisal system that preceded it. These new standards were used as a 'yard stick' to appraise teachers assessing them on whether they had met their own professional development targets (Reward and Incentives Group, 2006). These standards and targets shaped teacher professionalism. The standards were a requirement by the government and made teaching into, what Evans (2011, p.862) refers to as, a 'professionalism that is demanded'.

In 2012, the teaching standards were reviewed and changed again by the Conservative/ Liberal Democrat Coalition. Reflective practice was reaffirmed as an important part of being a professional teacher (DfE, 2012, no page number):

... [a teacher must] reflect systematically on the effectiveness of lessons and approaches to teaching.

To what extent and how this standard is met is dependent on the approach taken by the teacher educator but it is clear from these new standards that there is greater emphasis on the key elements of teaching (DfE, 2010, Para. 2.35). After the Coalition's 2010 White Paper: The Importance of Teaching, there was a shift in the government's approach to teacher education and what it means to be a teacher. There has been an on-going debate over whether teaching is a profession rather than a craft; it can be argued this debate is illustrated in different government stances towards teacher education.

In the last two publications of teaching standards the main thrust was on what teachers should be able to do. The 2007 standards can be divided into three elements: behaviour, attitudinal and intellectual (Kolsaker, 2008). Behaviour standards state what teachers physically apply at school, attitudinal are the attitudes they hold and believe and the intellectual relate to their knowledge and understanding. Evans (2011) used this framework to deconstruct the 2007 teaching standards. She exposed the prescriptive nature of the key components of the standards, namely that teachers should do and how they should do it. She points out that: "the extent to which they analyse and rationalise their practice scarcely features'(p.861). The emphasis on what teachers should be able to do continue to dominate the new 2012 standards. Reflective practice did appear in both the 2007 and 2012 Teaching Standards (see above) but was not central. The standards were mostly dominated by teacher's behaviour and action rather than critique or analysis. 


\section{Is reflective practice a necessity for the teaching profession and teacher professionalism?}

There is a well-documented debate over whether teaching is a profession or not. This is not the same debate as the matter of teaching professionalism, although of course there are links. According to Becks and Young $(2005, \mathrm{p}$.188) there are a number of traits that describe a profession. Firstly a profession has a 'collective autonomy' over its professional training and it controls the entrance requirements. Secondly, there is a body of knowledge that is specific to that profession and one needs that knowledge to be a 'member' of that profession. Thirdly, there is a code of practice, ethics and behaviour and if this code of practice is not upheld then a member will be excluded. By analysing these characteristics of a profession it is difficult to uphold teaching as a full profession (Gamble, 2010). Beck (2008) argues that no modern 'profession' any longer meets all these traits. Most professions are now controlled by the state rather than being a corporate body of independent practitioners and this is true for teaching. However, most theorists argue one of the defining traits of a profession is the existence of a required body of knowledge (Kerchner \& Caufman, 1995).

In both the 2010 White Paper: The Importance of Teaching (DfE, 2010) and the 2010 White Paper: The Case for Change, teaching is repeatedly referred to as a 'craft'. Michael Gove, Secretary of State for Education, in a speech to the National College Annual Conference in June, 2010 stated:

Teaching is a craft and it is best learnt as an apprentice observing a master craftsman or woman. Watching others, and being rigorously observed yourself as you develop, is the best route to acquiring mastery in the classroom. (Gove, 2010, no page number)

This signalled a movement in teacher education towards 'on the job' training. It prefaced an increased role for schools to train teachers through the School Direct programme. In the two government papers cited above, the role of HEIs, in ITE, was diminished. There was, and continues to be, a movement towards skill based competency training rather than teacher education. With the absence of HEIs from teacher education there is a possibility that the theory for practice will be missing. Pratte and Rury (1991) argue that teaching is more like a 'craft-profession' as there is no common 'teacher knowledge'; the knowledge required to teach is as much practical as pedagogical. There is the argument that the body of knowledge provided by HEIs is no longer needed; but the activity of reflection requires a broad base of knowledge which is unlikely to be provided by schools. The knowledge base within a school 
is not critiqued to the same extent as the knowledge delivered by a HEI provider, and so it may recreate existing knowledge rather than produce new knowledge. The knowledge, provided with school based training, is likely to be morphostatic rather than morphogentic as it is a replication of knowledge of what already exists.

Even if student teachers engage in reflective practice there is still a question about how they can continuously improve. They can only improve if they have access to the knowledge required for self-development. Hobbs (2007) argues that student teachers have difficulty reflecting critically when they only have a perceived understanding of how teachers should be and how pupils should behave. Other writers, such as Roberts (1998), point out that student teachers may not be ready or able to reflect as they have yet to master the requirements of professionalism. Reflective practice can only be effective if the student teacher has the knowledge to engage in reflectivity. Having the knowledge to critique a practice is an important part of professionalism but this area is being eroded by the movement of ITE away from HEIs (DfE, 2010). If a student teacher does not learn the theories that illustrate alternative practice then only one practice can be reflected upon, diminishing the outcome of reflective practice.

The debate about whether teaching is a profession, or not, is important for the future of reflective practice in ITE. If a 'body of knowledge' is no longer needed then where does the tacit knowledge come from that is needed for reflection? Within the teaching standards student teachers are required to reflect on their lessons and improve them; this can only happen if they have the breadth of specialist knowledge to be able to reflect and improve upon. There is the argument, which the current government believes, that teaching can be learnt 'on the job', but the 'body of knowledge' present within schools is limited by the social structure teachers have to work within. Hodgson (2014) comments that often teachers do not have the time that HEI tutors have to read about new developments, within their specialist subject areas, therefore they are not able to expand the knowledge base of the student teacher. In this case the movement, to school based training, is not only a movement away from teaching being a profession but may restrict the capability of meeting the teaching standards laid down by the state itself.

Professionalism is a word that has a multitude of interpretations and fluidity (Friedson, 1994). Troman (1996, p.476) understood the word to be socially constructed and is best understood 
in its social context: 'defined by management and expressed in its expectations of workers and the stipulation of tasks they will perform'. Evans (2008) argues there are four reified states of professionalism. The first has already been cited: 'professionalism that is demanded' with the standards of practice, for the profession, set down by the state. The second is 'professionalism that is prescribed'. This professionalism is the practice which is demanded by analysts. 'Professionalism that is enacted' is that which is observed by 'outsiders' looking at the professional practice and is how the practice is interpreted. The last state of professionalism is 'deduced' or 'assumed professionalism' and this is the practice that is sustained no matter how much the policy of that professionalism changes. It is the traditions that are upheld by that profession.

According to Wilkins (2011) it is the 'professionalism that is enacted' that is most important as this is what actually happens. Even though the demands of professionalism change, depending on policy, enacted professionalism can adapt and change depending on the dynamic nature of the agent. In the case of teachers their professionalism changes with governments and ideological shifts, but Wilkins argues that teachers will constantly adapt their practice to what best suits their teaching and pupils, irrespective of policy. This is the difference in professional practice that Evans (2011) refers to, as the macro and micro levels.

The macro level of professional practice is the demanded professionalism by the state whereas the micro level is 'about an individual discerning a better way of teaching...' (Evans, 2011, p. 865). It is the cognitive processes of the teachers, themselves, which leads to professional development; this is achieved through reflective practice. Even though at a macro level of professionalism the practice of the student teacher is demanded by the state; the teacher is also contributing to their own professionalism through reflective practice. If reflective practice is seen, traditionally, as a component of teacher professionalism then this practice will be sustained even if it does not have a large documentary presence in the teaching standards, but there is still a question over the knowledge the student teacher needs to reflect on their lessons and education as a whole.

\section{Conclusion}

Throughout this paper I have referred to teacher education rather than teacher training. Training is traditionally linked to learning a 'craft' through instruction, observation and 
practice. There is an assumption therefore that by watching practicing teachers a student teacher can learn how to teach. Teacher education, in contrast is, or should be educating the student teacher about the theory underpinning practice, the policies that inform practice and the practices themselves whilst arming them with the ability to critique all three and to improve their practice. It is educating the student teachers to be both reflective and reflexive and to know there are alternatives to what is prescribed by the state.

The teaching standards, introduced in 2010 , focus on the craft of teaching. These standards represent 'professionalism that is demanded'. Reflective practice still plays a part in these new standards, but only in the technical sense. Critical reflection does not exist in, and certainly would not be encouraged by, the new ideology of teacher education. Encouragement of critical reflection is, however, needed to inject new ways of thinking. If the student teachers are only judged by how well they meet a 'standard', then they are less likely to think 'outside the box' and create new ways of seeing and teaching. The student teachers need to question the structures that limit them rather than take them for granted. Critical reflection is important if a student teacher is to find the best way to improve the education of their pupils.

As a practice, reflexivity is not part of the teaching standards and so, if it does occur, it is part of 'professionalism that is enacted' (Evans, 2011). This would be a practice that happens irrespective of whether the state demands it or not. Although a number of theorists argue this is what is missing from teacher education I would go a step further and argue reflection and the technical approach to reflective practice, advocated by Schon (1987), is also missing from teacher education. Reflection is advocated by the Teaching Standards and is part of 'professionalism that is demanded'; however, the knowledge base that is needed for fruitful refection is missing from school based training. 


\section{References:}

Argyris, C., \& Schön, D. (1974). Theory in practice: Increasing professional effectiveness. San Francisco: Jossey-Bass.

Archer, M. S. (2007). Making our way through the world: human reflexivity and social mobility. Cambridge: Cambridge University Press.

Beck, J. (2008). Governmental Professionalism: Re-professionalising or de-professionalising teachers in England? British Journal of Educational Studies, 56(2): 119-143.

Beck, J., \& Young, M. (2005). The assault on the professions and the restructuring of academic and professional identities: a Bernsteinian analysis. British Journal of Sociology of Education, 30 (1) 3-14.

Bleakley, A. (1999). From reflective practice to holistic reflexivity. Studies in Higher Education, 24(3), 315 - 330.

Bourdieu, P. (1990). The logic of practice. Cambridge: Polity.

DfE. (1992). Initial Teacher Training; Secondary Phase (Circular 9/92). D. f. E, DfE: London.

DfEE. (1998). Standards for the Award of Qualified Teaching Status (Circular 4/98). DfEE: London.

DfE. (2010). The importance of teaching: the schools white paper 2010. Her Majesty's Stationery Office: London.

DfE. (2012a). Teachers' Standards. DfE. Crown Copyright: London.

Evans, L. (2008). Professionalism, professionality and the development of education professionals, British Journal of Educational Studies. 56.1, 20-38.

Evans, L. (2011). The 'shape' of teacher professionalism in England: professional standards, performance management, professional development, and the changes proposed in the 2010 White Paper, British Educational Research Journal, 37.5, 851-870.

Emery, H. (1998). A national curriculum for the education and training of teachers: an English perspective. Journal of In-Service Education, 24(2), 283-291.

Finlay, L. (2008). Reflecting on reflective practice. PBPL.

Finlay, L. (2003), Negotiating the swamp: the opportunity and challenge of reflexivity in research practice, Qualitative Research, August 2002, 2, 209-230.

Fook, J. G. (2006). Critical reflection: a review of contemporary literature and understandings. Maidenhead: Open University Press. 
Friedson,E. (1994). Professionalism Reborn: Theory, prophecy and policy. Cambridge, Polity Press.

Furlong, J. B., Miles, S., Whiting, C., \& Whitty, G. (2000). Teacher Education in Transition: Re-forming Professionalism? (Developing Teacher Education), Buckingham: Open University Press.

Gamble, J. (2010). Teacher professionalism: A literature review. Retrieved from: http://jet.org.za/publications/research/Gamble\%20TEACHER\%20PROFESSIONALI SM\%20-FINAL-\%20-2.pdfSections $1 \& 2,3-24$.

Yoshigaki, D. (n.d). What is sensei. The British Ki Soc

Ghaye, T. (2010). Teaching and learning through reflective practice: a practical guide for positive action. London: Routledge.

Gove, M. (2010). Speech to the National Annual Conference Birmingham (Monday, 16 June 2010) Retrieved from: http://www.education.gov.uk/inthenews/speeches/a0061371/michael-gove-to-thenational-college-annual-conference-birmingham.

Hobbs, V. (2007). Faking it or hating it: can reflective practice be forced? Reflective Practice, 8(3): 405-417.

Hodgson, J. (2014). Surveying the wreckage: the professional response to changes to initial Teacher training in the UK. English in Education, 48 (1), 7-25.

Kerchner, C. T., \& Caufman, K. D. (1995). Lurching toward professionalism: the saga of teacher unionism. The Elementary School Journal, 96 (1), 107-122.

Kolsaker, A. (2008) Academic professionalism in the managerialist era: a study of English universities, Studies in Higher Education, 33(5), 513-525.

Loughran, J. J. (1996). Developing reflective practice: Learning about teaching and learning through modelling. London: Falmer Press.

Pollard, A., \& Newman, M. (2010), Educational research: A foundation for teacher professionalism? The Routledge Education Studies Textbook. Arthur, J. \& Davies, I. (eds.). Abingdon: Routledge, 261-269.

Pratte, R., \& Rury, J. (1991). Teachers, professionalism, and craft. Teachers College Record, 93, (1), 59-72.

Rewards and Incentives Group. (2006). Performance management for teachers and head teachers: Guidance. (Nottingham, DfES Publications).

Reynolds, M. (1998). Reflection and critical reflection in management learning, Management Learning, 29 (2), 183-100. 
Roberts, J. (1998). Language Teacher Education. London: Arnold.

Robinson, W. (2006). Teacher training in England and Wales: Past, Present and Future Perspectives. Educational Research and Perspectives, 33(2), 19-36.

Schon, D. A. (1987). Educating the reflective practitioner. San Francisco, CA: Jossey-Bass.

Schon, D. A. (1995). Reflective practitioner: how professionals think in action, Arena.

Schon, D. A. (1991). The reflective practitioner: how professionals think in action. Aldershot: Avebury.

TDA .(2007). Professional Standards for Qualified Teacher Status and Requirements for Initial Teacher Training. Crown copyright.

Troman, G. (1996). The rise of the new professionals? The restructuring of primary teachers' work and professionalism. British Journal of Sociology of Education, 17 (4), 473-487.

TTA. (2002). Qualifying to Teach: Professional Standards for Qualified Teacher Status and Requirements for Initial Teacher Training. DfE: London.

Whitty, G. (2006). Education(al) research and educational policy making; is conflict inevitable? British Educational Research Journal. 32(2): 159-176.

Wilkins, C. (2011) Professionalism and the post-performative teacher: new teachers reflect On autonomy and accountability in the English school system, Professional Development in Education, 37(3), 389-409.

Zeichner, K. M. (1996). Reflective teaching: an introduction. Mahwah, N.J, L. Erlbaum Associates. 